\title{
PENGARUH PENDEKATAN OPEN-ENDED SETTING MODEL PEMBELAJARAN KOOPERATIF TIPE STAD TERHADAP PENINGKATAN KEMAMPUAN BERPIKIR KRITIS MATEMATIK SISWA
}

\author{
Zulham Alfari ${ }^{1)}$, Mustamin Anggo ${ }^{2)}$, Awaludin ${ }^{3)}$ \\ ${ }^{1)}$ Alumni Jurusan Pendidikan Matematika, ${ }^{2}$ Dosen Jurusan Pendidikan Matematika FKIP \\ Universitas Halu Oleo Email : Zulhamalfari@gmail.com; \\ mustaminanggo@yahoo.com; awaludinrahmat78@gmail.com
}

\begin{abstract}
Abstrak
Penelitian ini dilatarbelakangi oleh rendahnya kemampuan berpikir kritis matematik siswa. Desain penelitian adalah one-pretest-postest group design. Populasi dalam penelitian ini adalah seluruh siswa kelas VII SMP Negeri 1 Wakorumba Selatan. Teknik pengambilan sampel dilakukan dengan purposive sampling dan teknik penentuan kelas eksperimen dengan simple random sampling. Dari hasil analisis data dan pembahasan diperoleh kesimpulan: 1) Kemampuan berpikir kritis matematik setelah diajar dengan pendekatan open-ended setting model pembelajaran kooperatif tipe STAD di kelas VII SMP Negeri 1 Wakorumba paling banyak termasuk dalam kategori tinggi, 2) Peningkatan kemampuan berpikir kritis matematik yang diajar dengan pendekatan open-ended setting model pembelajaran kooperatif tipe STAD di kelas VII SMP Negeri 1 Wakorumba Selatan paling banyak termasuk dalam kategori sedang, dan 3) Terdapat pengaruh pendekatan open-ended setting model pembelajaran kooperatif tipe STAD terhadap peningkatan kemampuan berpikir kritis matematik siswa di kelas VII SMP Negeri 1 Wakorumba Selatan.
\end{abstract}

Kata Kunci: pendekatan open-ended, model pembelajaran kooperatif, berpikir kritis matematik.

\section{THE EFFECT OF OPEN-ENDED APPROACH OF COOPERATIVE SETTING TYPE STAD TO ENHANCEMENT MATH CRITICAL THINGKING SKILLS}

\begin{abstract}
This study is motived by the low math critical thingking skills of students. The design is one-pretestpostest group design. The population this study are all students of $1^{\text {st }}$ Grade SMP Negeri 1 Wakorumba Selatan. The sampling technique is purposive and simple random to determine of group class. From the data analysis and discussion of the conclusion: 1) The math critical thingking skills after being taught with open-ended approach of cooperative setting type STAD in $1^{\text {st }}$ Grade SMP Negeri 1 Wakorumba Selatan at most including the high category, 2) The enhancement of math critical thingking skills who were taught with open-ended approach of cooperative setting type STAD in $1^{\text {st }}$ Grade SMP Negeri 1 Wakorumba Selatan at most including the medium category, and 3) There is influence open-ended approach of cooperative setting type STAD to enhancement critical thingking skills of students in $1^{\text {st }}$ Grade SMP Negeri 1 Wakorumba Selatan.
\end{abstract}

Keywords: open-ended approach, cooperative model, critical thingking skills. 


\section{Pendahuluan}

Pendidikan, kemampuan, dan pengetahuan merupakan salah satu modal yang kita miliki untuk hidup di zaman serba sulit ini. Tujuan pendidikan secara umum dapat dipahami sebagai upaya pengembangan keterampilan diri, minat dan bakat sehingga terjadi pendewasaan diri dalam memecahkan suatu masalah. Oleh karena itu, pendidikan harus mampu menghasilkan kecakapan hidup (life skill). Salah satunya adalah kemampuan berpikir tingkat tinggi.

Pembentukan kemampuan berpikir idealnya ditanamkan pada jenjang Sekolah Menengah Pertama (SMP) karena pada jenjang ini pengerjaaan logis sudah dapat dikerjakan tanpa bantuan dari benda-benda konkrit sehingga kemampuan berpikir sudah mulai dilatih. Selain itu, dalam Kurikulum Pendidikan Nasional standar kelulusan siswa SMP untuk pelajaran matematika adalah menunjukan kemampuan berpikir logis, kritis, kreatif dan inovatif, menunjukkan kemampuan belajar secara mandiri sesuai dengan potensi yang dimilikinya dan menunjukkan kemampuan menganalisis dan memecahkan masalah dalam kehidupan sehari-hari. Walaupun demikian, pembelajaran di kelas belum memberikan kesempatan kepada siswa untuk mengembangkan kemampuan berpikir kritisnya.

Menurut Suherman (2003: 57) dalam pembelajaran matematika, para siswa dibiasakan untuk memperoleh pemahaman melalui pengalaman tentang sifat-sifat yang dimiliki dan yang tidak dimiliki dari sekumpulan objek (abstraksi). Sedangkan menurut Karso (2011: 40) pembelajaran matematika adalah belajar konsep dan struktur yang terdapat dalam bahanbahan yang sedang dipelajari, serta mencari hubungan di antara konsep dan struktur tersebut.

Salah satu pendekatan pembelajaran yang membiasakan siswa untuk memperoleh pemahaman secara bebas dari objek matematika adalah pendekatan open-ended. Ciri khas dari pendekatan ini adalah memberikan siswa masalah matematika yang bersifat terbuka. Menurut Inprasitha (2006: 170-171) pendekatan open-ended merupakan pendekatan pembelajaran dengan melibatkan siswa dalam masalah terbuka yaitu masalah yang memiliki beberapa jawaban yang benar. Dalam pendekatan ini, suatu masalah terbuka terlebih dahulu diajukan kepada siswa, kemudian dilanjutkan dengan memberikan banyak jawaban yang benar terhadap masalah yang diberikan untuk memberikan pengalaman dalam menemukan sesuatu yang baru selama proses pemecahan masalah.

Menurut Nohda (2008: 7) tujuan dari pendekatan open-ended adalah untuk mendorong kemampuan berpikir matematik melalui problem solving secara simultan. Menurut Becker \& Shimada (2007: 1) masalah open-ended adalah masalah yang harus memberi siswa pengalaman menemukan sesuatu yang baru dalam prosesnya.

Menurut Mahmudi (2008: 3) aspek keterbukaan soal dapat diklasifikasikan ke dalam 3 tipe, yaitu

1. Terbuka proses penyelesaiannya, yakni soal itu memiliki beragam cara penyelesaian.

2. Terbuka hasil akhirnya, yakni soal itu memiliki banyak jawaban yang benar.

3. Terbuka pengembangan lanjutannya, yakni ketika siswa telah menyelesaikan suatu, selanjutnya mereka dapat mengembangkan soal baru dengan mengubah syarat atau kondisi pada soal yang telah diselesaikan.

Penggunaan pendekatan open-ended dapat mengarahkan siswa untuk berpikir bebas, bagaimana cara mereka menemukan sendiri penyelesaian dari suatu masalah sehingga dapat meningkatkan kualitas pembelajaran matematika sebagai sarana untuk mengembangkan kemampuan berpikir kritis matematik. Kemampuan berpikir kritis matematik akan mudah dicapai jika siswa terlibat secara aktif dalam proses pembelajaran. Untuk itu, diperlukan suatu setting pembelajaran yang tepat.

Menurut teori sosial Vigotsky (Sani, 2015:19) aktivitas siswa yang aktif seharusnya didukung dengan lingkungan belajar yang menitikberatkan kerja sama. Peserta didik berpartisipasi dalam kegiatan sosial tanpa makna, kemudian terjadi internalisasi atau pengendapan pengetahuan dan pemaknaan atau konstruksi pengetahuan baru, serta perubahan atau transformasi pengetahuan. Penguatan pemahaman yang lebih tinggi pada umumnya muncul dalam percakapan dan kerja sama antarindividu sebelum pemahaman yang lebih tinggi itu terserap ke dalam individu tersebut. Lingkungan belajar yang saling bekerja sama akan membantu siswa dalam mengontruksi pengetahuan. Selanjutnya, pengetahuan tersebut 
dapat digunakan untuk menyelesaikan masalah terbuka yang diberikan oleh guru.

Salah satu alternatif yang dapat memicu keaktifan siswa dalam proses pembelajaran adalah pembelajaran kooperatif tipe Student Teams Achievement Divisions (STAD). Menurut Slavin (Eminingsih, 2013: 31) model pembelajaran kooperatif tipe Student Teams Achievement Division (STAD) merupakan model pembelajaran kooperatif yang paling sederhana dan merupakan model yang paling baik untuk permulaan bagi guru yang baru menggunakan pembelajaran kooperatif. Gagasan utama Student Teams Achievement Division (STAD) adalah untuk memotivasi siswa supaya saling mendukung dan membantu satu sama lain dalam menguasai kemampuan yang diajarkan oleh guru. Menurut Krismantono (2003:16) bagian esensial dari model pembelajaran kooperatif tipe Student Teams Achievement Divisions (STAD) adalah adanya kerja sama anggota kelompok dan kompetisi antara kelompok. Siswa bekerja di kelompok untuk belajar dari temannya serta mengajar temannya.

Adapun langkah-langkah pendekatan open-ended setting model pembelajaran kooperatif tipe STAD adalah sebagai berikut.

1. Guru menyampaikan tujuan dan memotivasi peserta didik.

2. Guru menyampaikan materi ajar sesuai dengan kompetensi dasar yang akan dicapai.

3. Guru membentuk kelompok kecil yang terdiri dari 4-5 orang. Pemilihan anggota kelompok dilakukan secara heterogen.

4. Guru memberikan bahan ajar dan Lembar Kerja Peserta Didik (LKPD) kepada semua kelompok. Masalah yang disajikan dalam LKPD merupakan masalah/soal terbuka (jawaban dan cara pengerjaan).

5. Guru meminta siswa untuk menuliskan ide masing-masing terkait dengan masalah/soal terbuka (jawaban dan cara pengerjaan).

6. Guru meminta siswa berdiskusi dengan kelompoknya untuk menyelesaikan masalah/soal terbuka tersebut.

7. Guru membimbing kelompok-kelompok yang mengalami kesulitan dalam mengerjakan masalah/soal terbuka.

8. Guru memberikan silang tanya antar kelompok untuk memberikan penilaian secara individual maupun kelompok.
9. Guru memberi penghargaan kepada kelompok yang memiliki skor silang tanya yang baik.

10. Guru memberi penguatan pemahaman terhadap materi yang diajarkan.

Keberhasilan pendekatan open-ended setting model pembelajaran kooperatif tipe STAD dalam meningkatkan kemampuan berpikir kritis matematik siswa dapat dilihat dengan mengukur beberapa indikator kemampuan berpikir kritis matematik dalam menyelesaikan masalah/soal terbuka. Menurut Jenicek (2006: 1) berpikir kritis dapat diartikan sebagai proses juga suatu kemampuan. Proses dan kemampuan tersebut digunakan untuk memahami konsep, menerapkan, mensintesis, dan mengevaluasi informasi yang didapat atau informasi yang dihasilkan.

Menurut Fisher (2008: 8) beberapa keterampilan berpikir kritis yang sangat penting, khususnya bagaimana:

a. Mengidentifikasi elemen-elemen dalam kasus yang dipikirkan khususnya alasanalasan dan kesimpulan-kesimpulan.

b. Mengidentifikasi dan mengevaluasi asumsiasumsi.

c. Mengklarifikasi dan menginterpretasi pernyataan-pernyataan dan gagasangagasan.

d. Menilai akseptabilitas, khususnya kredibilitas, klaim-klaim.

e. Mangevaluasi argumen-argumen yang beragam jenisnya.

f. Menganalisis, mengevaluasi, dan menghasilkan penjelasan-penjelasan.

g. Menganalisis, mengevaluasi,dan membuat keputusan-keputusan.

h. Menarik inferensi-inferensi.

i. Menghasilkan argumen-argumen.

Tidak semua informasi yang diterima dapat dijadikan panduan dalam tindakan. Demikian halnya dengan informasi yang dihasilkan tidak selalu merupakan informasi yang benar. Kemampuan untuk menelaah informasi dalam matematika berkaitan dengan kemampuan menganalisis yakni siswa dapat mengorganisasikan informasi matematika.

Sehubungan dengan pendekatan pembelajaran dalam penelitian ini maka indikator yang digunakan untuk mengetahui peningkatan kemampuan berpikir kritis matematik siswa seperti yang dikatakan Ismaimuza (Lambertus, 2014: 97), yaitu sebagai berikut: 
1. Menganalisis merupakan suatu keterampilan menguraikan struktur ke dalam komponen-komponen agar mengetahui pengorganisasian struktur tersebut. Aspek menganalisis meliputi menuliskan apa yang diketahui dan ditanyakan dari soal.

2. Mengidentifikasi konsep merupakan menguraikan dan memahami berbagai aspek secara bertahap agar sampai pada suatu formula baru. Aspek mengidentifikasi konsep meliputi dapat menentukan konsep/definisi/teorema dalam menyelesaikan permasalahan dengan jelas dan tepat.

3. Menghubungkan antarkonsep merupakan menggabungkan bagian-bagian menjadi sebuah bentukan atau temuan baru. Aspek menghubungkan konsep meliputi dapat menerapkan konsep/definisi/teorema dalam menyelesaikan masalah.

4. Memecahkan masalah merupakan aplikasi konsep ke dalam beberapa pengertian baru. Aspek memecahkan masalah meliputi dapat menunjukan hasil utama dan prosedural matematis (model matematis) dalam penyelesaian masalah/penentuan solusi/jawaban.

5. Mengevaluasi merupakan memberikan penilaian tentang nilai yang diukur dengan menggunakan standar tertentu. Aspek mengevaluasi meliputi memeriksa kebenaran dari suatu permasalahan.

\section{Metode}

Penelitian eksperimen ini dilaksanakan di SMP Negeri 1 Wakorumba Selatan pada semester genap tahun ajaran 2017/2018. Desain dari penelitian ini disajikan sebagai berikut.

$$
\begin{array}{lll}
\mathbf{O}_{1} & \mathrm{X} & \mathrm{O}_{2}
\end{array}
$$

2009: 76)

(Sugiyono,

Keterangan:

$\mathrm{O}_{1}=$ Hasil pretest siswa sebelum diberikan perlakuan dengan pendekatan openended setting model pembelajaran kooperatif tipe STAD.

$\mathrm{X}=$ Perlakuan diberikan kepada siswa berupa pendekatan open-ended setting model pembelajaran kooperatif tipe STAD.

$\mathrm{O}_{2}=$ Hasil posttest siswa setelah diberi perlakuan pendekatan open-ended setting model pembelajaran kooperatif tipe STAD.

Populasi dalam penelitian ini adalah seluruh siswa kelas VII SMP Negeri 1 Wakorumba Selatan. Secara rinci disajikan dalam Tabel 1 berikut

Tabel 1

Data Populasi dan Hasil Belajar Matematika Siswa Kelas VII SMP Negeri 1 Wakorumba Selatan Menurut Ulangan Akhir Semester Ganjil Tahun Ajaran 2017/2018

\begin{tabular}{|c|c|c|c|c|c|c|}
\hline \multirow{2}{*}{ No. } & \multirow{2}{*}{ Kelas } & \multicolumn{2}{|c|}{ Banyak Siswa (orang) } & \multirow{2}{*}{$\begin{array}{l}\text { Jumlah } \\
\text { (orang) }\end{array}$} & Rata-rata & Varians \\
\cline { 3 - 6 } & & $\mathrm{L}$ & $\mathrm{P}$ & 25 & 60,22 & 73,22 \\
\hline 1. & $\mathrm{VII}_{1}$ & 11 & 14 & 24 & 59,75 & 40,75 \\
\hline 2. & $\mathrm{VII}_{2}$ & 9 & 15 & 24 & 59,31 & 39,58 \\
\hline 3. & $\mathrm{VII}_{3}$ & 8 & 17 & 24 & $\begin{array}{l}\text { satu variabel terikat, yaitu } \\
\text { kemampuan berpikir kritis }\end{array}$ \\
\\
Sampel dalam penelitian ini ditentukan \\
menggunakan teknik purposive
\end{tabular}
yang memiliki varians yang relatif kecil terhadap rata-rata hasil belajar matematika siswa, yaitu $\mathrm{VII}_{2}$ dan $\mathrm{VII}_{3}$. Selanjutnya, untuk menentukan kelas eksperimen dilakukan dengan menggunakan teknik simple random sampling. Hasilnya diperoleh kelas $\mathrm{VII}_{3}$ sebagai kelas eksperimen.

Variabel penelitian terdiri dari satu variabel bebas, yaitu pendekatan open-ended setting model pembelajaran kooperatif tipe

Instrumen dalam penelitian ini adalah tes uraian yang terdiri dari pretest dan posttest. Sebelum instrumen ini digunakan terlebih dahulu dilakukan uji validitas konstruk melalui penilaian panelis. Tujuannya adalah untuk mengoreksi instrumen yang telah disusun oleh peneliti apakah pertanyaan atau pernyataan dalam setiap butir instrumen telah mengukur setiap indikator yang hendak diukur dengan sesungguhnya atau tidak. Selanjutnya, soal-soal 
yang dinyatakan valid oleh panelis diberikan kepada siswa. Hasil pekerjaan siswa dikumpulkan oleh peneliti untuk diperiksa dan diberi nilai.

Untuk tes uraian, tingkat kevalidannya dihitung dengan menggunakan rumus korelasi product moment sebagai berikut (Sundayana, 2014 : 59-60).

$$
r_{x y}=\frac{N \sum X Y-\sum X \sum Y}{\sqrt{\left.\left(N \sum X^{2}-\left(\sum X\right)^{2}\right)\left(N \sum Y^{2}-\left(\sum Y\right)^{2}\right)\right)}}
$$

Keterangan:

$\mathrm{r}_{\mathrm{xy}}=$ Koefisien korelasi

$N=$ Jumlah responden

$X=$ Skor item butir soal

$Y=$ Jumlah skor total tiap soal

Adapun kriteria pengujian sebagai berikut.

a) Jika $r_{X Y} \geq r_{\text {tabel }}$ dengan $\alpha=0,05$ maka butir soal tersebut valid.

b) Jika $r_{X Y}<r_{\text {tabel }}$ dengan $\alpha=0,05$ maka butir soal tersebut tidak valid

Menurut Usman \& Akbar (2008: 291) untuk menentukan ketepatan butir instrumen menggunakan rumus Alpha Cronbanch, dengan formula:

$$
r_{11}=\frac{k}{k-1}\left\{1-\frac{\sum s i^{2}}{s t^{2}}\right\}
$$

Keterangan

$\mathrm{r}_{11}=$ Reliabilitas

$k=$ Banyak item

$s i^{2}=$ Varians skor butir

$s t^{2}=$ Varians skor total

Teknik analisis data dalam penelitian ini menggunakan dua teknik analisis, yaitu analisis deskriptif dan analisis inferensial.Analisis deskriptif merupakan analisis yang digunakan untuk mendeskripsikan data penelitian yang berupa perolehan nilai ratarata, nilai median, nilai modus, varians, nilai maksimum, nilai minimum dan bentuk persentase.

Analisis inferensial dimaksudkan untuk menguji hipotesis penelitian, yang diawali dengan uji normalitas sebagai uji prasyarat hipotesis. Jika data yang dikumpulkan berdistribusi normal, maka uji statistik yang digunakan adalah uji t satu sampel (one sample).

Uji normalitas dalam penelitian ini bertujuan untuk melihat apakah data pretest dan posttest kelas eksperimen serta pretest dan posttest kelas kontrol yang diperoleh berdistribusi normal atau tidak. Uji normalitas akan menggunakan uji Kolmogrov-Sminorv dengan bantuan SPSS. Hipotesisnya adalah sebagai berikut:

$\mathrm{H}_{0}$ : Rerata normalized gain kemampuan berpikir kritis matematik kelas eksperimen berasal dari populasi yang berdistribusi normal.

$\mathrm{H}_{1}$ : Rerata normalized gain kemampuan berpikir kritis matematik siswa kelas eksperimen berasal dari populasi yang berdistribusi tidak normal.

Kriteria jika nilai Sig $>0,05$, maka distribusi data dinyatakan normal. Dan apabila nilai Sig $\leq 0,05$, distribusi data dinyatakan tidak normal.

Uji hipotesis yang digunakan dalam penelitian ini adalah uji t satu sampel (one sample) dengan rumus:

$$
t=\frac{\bar{x}-\mu_{0}}{s / \sqrt{n}}
$$

(Irianto,

Keterangan:

$$
\text { 2015: 39) }
$$

$\bar{x}=$ Rerata normalized gain kelas eksperimen

$\mu_{0} \quad=$ Skor yang dihipotesiskan (0)

$s \quad=$ Simpangan baku

$n=$ Banyaknya siswa kelas eksperimen

Hipotesis yang diajukan.

$\mathrm{H}_{0}=$ Tidak terdapat pengaruh pendekatan openended setting model pembelajaran kooperatif tipe STAD terhadap peningkatan kemampuan berpikir kritis matematik siswa kelas VII SMP Negeri 1 Wakorumba Selatan.

$\mathrm{H}_{1}=$ Terdapat pengaruh pendekatan openended setting model pembelajaran kooperatif tipe STAD terhadap peningkatan kemampuan berpikir kritis matematik siswa kelas VII SMP Negeri 1 Wakorumba Selatan.

$$
\begin{aligned}
& \mathrm{H}_{0}: \mu_{1}=0 \\
& \mathrm{H}_{1}: \mu_{1} \neq 0
\end{aligned}
$$

Keterangan:

$\mu_{1}=$ Rerata normalized gain kemampuan berpikir kritis matematik siswa yang diajar dengan pendekatan open-ended setting model pembelajaran kooperatif tipe STAD. 
Hasil

Hasil dalam penelitian ini meliputi (1) analisis deskriptif, yakni menggambarkan karakter data secara deskriptif dan (2) analisis inferensial, yaitu untuk melihat peningkatan kemampuan berpikir kritis matematik siswa melalui uji t satu sampel (one sample). Hasil analisis deskriptif nilai pretest dan posttest kemampuan berpikir kritis matematik siswa disajikan dalam Tabel 2 berikut.

Tabel 2

Hasil Deskriptif Statistik Nilai Pretest dan Posttest

\begin{tabular}{|l|l|c|c|}
\hline \multicolumn{3}{|c|}{ Statistics } \\
\hline \multirow{2}{*}{$\mathrm{N}$} & Valid & Pretest & Posttest \\
\cline { 2 - 4 } & Missing & 24 & 24 \\
\hline Mean & 0 & 0 \\
\hline Median & 27.2142 & 67.9717 \\
\hline Mode & 28.1300 & 67.1900 \\
\hline Std. Deviation & $18.75^{\mathrm{a}}$ & 65.63 \\
\hline Variance & 12.3812 & 10.51705 \\
\hline Minimum & 153.294 & 110.608 \\
\hline Maximum & 6.25 & 43.75 \\
\hline
\end{tabular}

Sumber: Data Primer Diolah dengan SPSS Versi 16.0

Hasil analisis Tabel 4 menunjukkan bahwa: (1) rata-rata nilai kemampuan berpikir kritis matematik siswa setelah diajar dengan pendekatan open-ended setting model pembelajaran kooperatif tipe STAD, yaitu 67,97 lebih baik dibandingkan dengan sebelum diajar dengan pendekatan open-ended setting model pembelajaran kooperatif tipe STAD, yaitu 27,21 ; (2) nilai median posttest yaitu, 67,19 lebih baik dibandingkan dengan nilai median pretest, yaitu 28,13; (3) nilai modus posttest, yaitu 65,63 lebih baik dibandingkan dengan nilai modus pretest yaitu, 18,75. Ini menunjukkan bahwa kemampuan berpikir kritis matematik siswa setelah diajar dengan pendekatan open-ended setting model pembelajaran kooperatif tipe STAD termasuk dalam kategori sangat tinggi; (4) varians posttest yaitu, 110,60 lebih kecil dibandingkan pretest yaitu, 153, 29; (5) nilai minimum posttest, yaitu 43,75 lebih besar dibandingkan dengan pretest, yaitu 6,25 dan (6) nilai maksimum posttest, yaitu 84,38 lebih besar dibandingkan dengan pretest, yaitu 50,00. Fakta diatas menunjukkan bahwa ada indikasi peningkatan kemampuan berpikir kritis matematik siswa setelah diajar dengan pendekatan open-ended setting model pembelajaran kooperatif tipe STAD.

Adapun distribusi data hasil pretest dan posttest kemampuan berpikir kritis matematik dapat dilihat pada Tabel 3 berikut.

Tabel 3

Kriteria Nilai Pretest dan Posttest Kemampuan Berpikir Kritis Matematik

\begin{tabular}{|c|c|c|c|c|c|}
\hline \multirow{2}{*}{ Nilai } & \multirow{2}{*}{ Kategori } & \multicolumn{2}{|c|}{ Pretest } & \multicolumn{2}{c|}{ Posttest } \\
\cline { 3 - 6 } & & Frekuensi & Presentase (\%) & Frekuensi & Presentase (\%) \\
\hline$x>80$ & Sangat tinggi & 0 & 0 & 4 & 16,67 \\
\hline $60<x \leq 80$ & Tinggi & 0 & 0 & 15 & 62,5 \\
\hline $40<x \leq 60$ & Sedang & 5 & 20,83 & 5 & 20,83 \\
\hline $20<x \leq 40$ & Rendah & 10 & 41,67 & 0 & 0 \\
\hline$x \leq 20$ & Sangat rendah & 9 & 37,5 & 0 & 0 \\
\hline
\end{tabular}

Hasil analisis Tabel 3 di atas, terlihat bahwa rata-rata pretest, yaitu 27,21 terletak pada interval $20<x \leq 40$ dengan kategori rendah. Jadi, banyaknya siswa yang memperoleh nilai di atas atau sama dengan rata-rata, yaitu 15 orang. Atau jika dipresentasekan sebesar $62,5 \%$. Sedangkan, rata-rata posttest, yaitu 67,97 terletak pada interval $60<x \leq 80$ dengan kategori tinggi. Jadi, banyaknya siswa yang memperoleh nilai di atas atau sama dengan rata- 
rata, yaitu 19 orang. Atau jika dipresentasekan sebesar $79,17 \%$.

Data pretest dan posttest selanjutnya diolah dengan Microsoft Excel 2010 untuk melihat rerata normalized gain. Rerata normalized gain merupakan gambaran peningkatan kemampuan berpikir kritis matematik siswa. Klasifikasi data normalized gain kemampuan berpikir kritis matematik dan tiap indikatornya disajikan dalam Tabel 4 berikut.

Tabel 4

Klasifikasi Normalized Gain Kemampuan Berpikir Kritis Matematik

\begin{tabular}{|c|c|c|c|}
\hline Normalized Gain & Klasifikasi & Frekuensi & Persentase $(\%)$ \\
\hline$N$-Gain $<0,30$ & Rendah & 0 & 0 \\
\hline $0,30 \leq N$-Gain $\leq 0,70$ & Sedang & 14 & 58,33 \\
\hline$N$-Gain $>0,70$ & Tinggi & 10 & 41,67 \\
\hline Total & & 24 & 100 \\
\hline
\end{tabular}

Peningkatan kemampuan berpikir kritis matematik siswa paling banyak terdapat pada klasifikasi sedang yaitu pada interval $0,30 \leq G \leq$ 0,70 dengan jumlah 14 orang siswa dan 10 orang siswa lainnya terdapat pada klasifikasi tinggi, yaitu interval $G>0,70$. Ini menunjukkan peningkatan kemampuan berpikir kritis matematik kategori sedang dengan presentase $58,33 \%$. Sementara itu, sebanyak $41,67 \%$ siswa mengalami peningkatan kemampuan berpikir kritis matematik kategori tinggi.

bahwa lebih dari setengah siswa mengalami

Tabel 5

Klasifikasi Normalized Gain Tiap Indikator Kemampuan Berpikir Kritis Matematik

\begin{tabular}{|l|c|c|}
\hline \multicolumn{1}{|c|}{ Indikator } & Normalized Gain & Kategori \\
\hline Menganalisis & 0,74 & Tinggi \\
\hline Mengidentifikasi konsep & 0,46 & Sedang \\
\hline Menghubungkan antar konsep & 0,46 & Sedang \\
\hline Memecahkan masalah & 0,41 & Sedang \\
\hline Mengevaluasi & 0,53 & Sedang \\
\hline
\end{tabular}

Peningkatan tiap indikator kemampuan berpikir kritis matematik paling banyak terdapat pada kategori sedang. Ini menujukkan bahwa tidak ada lagi siswa yang tidak menggunakan kemampuan berpikir kritisnya. Sementara itu, matematik siswa kategori tinggi terdapat pada indikator menganaisis.

Hasil analisis deskriptif normalized gain kemampuan berpikir kritis matematik siswa disajikan dalam Tabel 6 berikut.

peningkatan indicator kemampuan berpikir kritis

Tabel 6

Hasil Deskriptif Statistik Data Normalized Gain

\begin{tabular}{|l|l|c|}
\hline \multicolumn{2}{|c|}{ Statistics } \\
\hline \multirow{2}{*}{$\mathrm{N}$} & Valid & 24 \\
\cline { 2 - 3 } & Missing & 0 \\
\hline Mean & .6088 \\
\hline Median & .6700 \\
\hline Mode & $.52^{\mathrm{a}}$ \\
\hline Std. Deviation & .14789 \\
\hline Variance & .022 \\
\hline Minimum & .31 \\
\hline Maximum & .81 \\
\hline
\end{tabular}

Sumber: Data Primer Diolah dengan SPSS Versi 16.0

Berdasarkan hasil analisis deskriptif normalized gain, yaitu 0,22. Ini menunjukkan diperoleh bahwa rata-rata normalized gain bahwa peningkatan kemampuan berpikir kritis termasuk dalam kategori sedang. Varians matematik siswa cukup baik. Dengan kata lain, 
peningkatan kemampuan berpikir kritis matematik siswa tersebar secara merata setelah diajar dengan pendekatan open-ended setting model pembelajara kooperatif tipe STAD. Standar deviasi normalized gain, yaitu 0,14. Nilai minimum normalized gain kemampuan berpikir kritis matematik, yaitu 0,31 dengan kategori sedang yang berarti bahwa tidak terdapat siswa yang tidak menggunakan kemampuan berpikir kritis matematiknya dengan baik. Nilai maksimum normalized gain kemampuan berpikir kritis matematik, yaitu 0,81 dengan kategori tinggi. Ini menunjukkan bahwa siswa tesebut telah mampu menggunakan kemampuan berpikir kritis matematiknya dengan baik.

Untuk mengetahui banyaknya siswa yang memperoleh peningkatan kemampuan berpikir kritis matematik di atas rata-rata maka disajikannlah hasil normalized gain dalam bentuk distribusi frekuensi.

Tabel 7

Distribusi Frekuensi Normalized Gain Kelas Eksperimen

\begin{tabular}{|c|c|c|c|c|}
\hline \multirow{2}{*}{ No } & \multirow{2}{*}{ Interval } & \multicolumn{3}{|c|}{ Frekuensi } \\
\hline & & Absolut & Relatif (\%) & Kumulatif $(\geq)$ \\
\hline 1. & $0,31-0,41$ & 2 & 8,33 & 24 \\
\hline 2. & $0,42-0,52$ & 7 & 29,17 & 22 \\
\hline 3. & $0,53-0,63$ & 2 & 8,33 & 15 \\
\hline 4. & $0,64-0,74$ & 8 & 33,33 & 13 \\
\hline 5. & $0,75-0,85$ & 5 & 20,84 & 5 \\
\hline & Jumlah & 24 & 100 & \\
\hline
\end{tabular}

Hasil analisis Tabel 7 di atas, terlihat bahwa nilai rata-rata normalized gain yaitu 0,61 terletak pada interval $0,53-0,63$. Jadi, banyaknya siswa yang memperoleh skor di atas atau sama dengan rata-rata tersebut, yaitu 15 orang. Atau jika dipresentasikan sebesar 62,5\%.

Uji normalitas dalam penelitian ini bertujuan untuk melihat apakah data pretest dan posttest kelas kontrol yang diperoleh berdistribusi normal atau tidak. Uji normalitas akan menggunakan uji Kolmogrov-Sminorv dengan bantuan SPSS. Uji ini diperukan untuk mengetahui apakah data yang dipereh bisa dioah dengan statistic parametrik atau tidak. Secara singkat hasi uji normalitas disajikan dalam tabel 8 berikut. posttest kelas eksperimen serta pretest dan

Tabel 8

Hasil Uji Normalitas Normalized Gain Kemampuan Berpikir Kritis Matematik

\begin{tabular}{|c|c|c|}
\hline & & $N$ Gain Kelas Eksperimen \\
\hline \multicolumn{2}{|l|}{$\mathrm{N}$} & 24 \\
\hline \multirow[t]{2}{*}{ Normal Parameters $^{\mathrm{a}}$} & Mean & .6087 \\
\hline & Std. Deviation & .14789 \\
\hline \multirow{3}{*}{$\begin{array}{l}\text { Most Extreme } \\
\text { Differences }\end{array}$} & Absolute & .202 \\
\hline & Positive & .101 \\
\hline & Negative & -.202 \\
\hline \multicolumn{2}{|c|}{ Kolmogorov-Smirnov Z } & .991 \\
\hline \multicolumn{2}{|l|}{ Asymp. Sig. (2-tailed) } & .280 \\
\hline
\end{tabular}
bahwa nilai Asymp. Sig. (2-tailed) untuk normalized gain kelas eksperimen, yaitu 0,280 > $\alpha$ (dengan $\alpha=0,05$ ), sehingga $\mathrm{H}_{0}$ diterima. Dengan demikian data normalized gain kemampuan berpikir kritis matematik berdistribusi normal. berdistribusi normal mengindikasikan bahwa data tersebut bisa diuji dengan statistik parametrik, yakni uji t satu sampel (one sample). Dengan bantuan softsware SPSS versi 16.0 hasil uji t satu sampel data normalized gain disajikan dalam Tabel 10 berikut. 
Tabel 9

Hasil Uji Peningkatan Kemampuan Berpikir Kritis Matematik Siswa

\begin{tabular}{|l|c|c|c|c|c|c|}
\hline & \multicolumn{5}{|c|}{ Test Value =0 } \\
\hline & $\mathrm{t}$ & $\mathrm{Df}$ & $\begin{array}{c}\text { Sig. (2- } \\
\text { tailed) }\end{array}$ & $\begin{array}{c}\text { Mean } \\
\text { Differenc } \\
\mathrm{e}\end{array}$ & $\begin{array}{c}\text { 95\% Confidence } \\
\text { Interval of the } \\
\text { Difference }\end{array}$ \\
\cline { 5 - 7 } & & & & & Lower & Upper \\
\hline $\begin{array}{l}N \text { Gain Kelas } \\
\text { Eksperimen }\end{array}$ & 20.165 & 23 & .000 & .60875 & .5463 & .6712 \\
\hline
\end{tabular}

Hasil analisis Tabel 9 di atas, terlihat bahwa nilai $t$ hitung normalized gain kelas eksperimen, yaitu 20,165 $>\mathrm{t}_{\text {tabel }(23,0,05)}=1,714$, sehingga $\mathrm{H}_{0}$ ditolak. Atau dengan melihat setengah Sig. (2-tailed), yaitu $=\frac{1}{2} 0,000<\alpha=$ 0,05 , sehingga $\mathrm{H}_{0}$ ditolak. Hal ini menunjukkan bahwa terdapat pengaruh pendekatan openended setting model pembelajaran kooperatif tipe STAD terhadap peningkatan kemampuan berpikir kritis matematik siswa kelas VII SMP Negeri 1 Wakorumba Selatan. Dengan kata lain, terdapat peningkatan secara signifikan kemampuan berpikir kritis matematik yang diajar dengan pendekatan open-ended dalam setting model pembelajaran kooperatif tipe STAD.

\section{Pembahasan}

Pelaksanaan pembelajaran matematika dalam penelitian ini menggunakan pendekatan open ended setting model pembelajaran kooperatif tipe STAD untuk kelas eksperimen. Awalnya, kelas eksperimen diberikan pretest. Pretest dimaksudkan untuk mengetahui kemampuan awal berpikir kritis matematik siswa terhadap materi segi empat sebelum diberi perlakuan pembelajaran dengan pendekatan open ended setting model pembelajaran kooperatif tipe STAD. selanjutnya, diberikan perlakuan dengan pembelajaran dengan pendekatan open ended setting model pembelajaran kooperatif tipe STAD. Rangkaian akhir dari penelitian ini adalah siswa diberikan posttest dengan tujuan untuk mengetahui kemampuan berpikir kritis matematik siswa terhadap materi segi empat setelah diberi perlakuan pembelajaran dengan pendekatan open ended setting model pembelajaran kooperatif tipe STAD.

Tes yang digunakan pada ke dua jenis tes ini adalah tes yang telah diujipaneliskan terhadap tiga orang panelis, yakni satu orang merupakan dosen jurusan pendidikan matematika FKIP UHO dan dua orang lainnya merupakan guru mata pelajaran matematika kelas SMP Negeri 1 Wakorumba Selatan. Berdasarkan penilaian panelis, semua butir soal pretest dan posttest dinyatakan valid. Selanjutnya, dilakukan uji validitas dan reliabilitas pada masing-masing jenis tes. Hasilnya menunjukkan bahwa semua jenis tes yang digunakan pada penelitian ini mampu mengukur apa yang hendak diukur, yaitu kemampuan berpikir kritis matematik siswa dan memiliki keterandalan yang cukup.

Pembelajaran matematika dengan pendekatan open-ended setting model pembelajaran kooperatif tipe STAD diterapkan pada kelas $\mathrm{VII}_{3}$ SMP Negeri 1 Wakorumba Selatan. Pembelajaran ini beorientasi pada masalah yang diselesaikan secara berkelompok. Tahapan pembelajarannya terdiri atas tiga kegiatan utama yaitu kegiatan pendahuluan, kegiatan pembelajaran (inti) dan kegiatan penutup. Tahapan kegiatan pendahuluan merupakan tahap awal pembelajaran matematika dengan pendekatan open-ended setting model pembelajaran kooperatif tipe STAD. Tujuannya adalah agar siswa mempersiapkan diri dalam mengikuti proses pembelajaran di kelas sekaligus memahami langkah-langkah pembelajaran dengan pendekatan open-ended setting model pembelajaran kooperatif tipe STAD.

Tahapan selanjutnya adalah tahapan kegiatan pembelajaran. Guru dalam hal ini Peneliti memberikan bahan ajar dan lembar kerja peserta didik pada setiap kelompok. Lembar kerja peserta didik berisi soal-soal terbuka materi segi empat baik dari segi jawaban maupun cara penyelesaian. Selanjutnya, guru meminta siswa untuk memberikan ide masingmasing terhadap soal-soal yang ada dalam lembar kerja peserta didik.Pada kegiatan ini siswa memiliki beragam ide. Aspek keterbukaan soal memacu setiap siswa untuk menggunakan pengetahuan yang dimilikinya secara 
komprehensif. Siswa yang kurang bisa tidak minder untuk memberikan solusi sesuai dengan pengetahuan yang dimilikinya. Kemudian, siswa diminta untuk berdiskusi dengan kelompoknya. Hal ini dimaksudkan untuk menghasilkan keputusan kelompok berupa jawaban atau penyelesaian dari soal-soal terbuka.

Kegiatan diskusi kelompok berdampak pada keaktifan siswa dalam proses pembelajaran serta distribusi pengetahuan pada tiap anggota kelompok. Setiap siswa memberikan alasan mengenai jawaban yang diperoleh. Pada tahap ini, guru bertindak sebagai fasilitator dengan memberikan bantuan kepada kelompok yang mengalami kesulitan dalam menyelesaikan lembar kerja peserta didik dengan memanfaatkan alat peraga. Walaupun demikian, pengetahuan tetap dikonstruksi sendiri oleh kelompok tersebut. Setelah semua kelompok menyelesaikan soal-soal yang terdapat dalam lembar kerja peserta didik sesuai dengan waktu yang ditetapkan, guru memberikan silang tanya antarkelompok. Setiap kelompok menunjuk perwakilannya untuk mempresentasikan hasil kerja kelompok mereka. Hasilnya, setiap kelompok menyajikan jawaban yang berbeda. Selanjutnya, guru memberi kesempatan kepada kelompok lain untuk menanggapi jawaban yang disajikan oleh tiap kelompok. Pada kegiatan ini, setiap kelompok mempertahankan jawaban kelompok mereka dengan alasan masingmasing. Keberagaman jawaban ini memperkaya pengetahuan matematik siswa. Namun, diperlukan peran guru untuk mengklarifikasi jawaban dari tiap-tiap kelompok jika ada yang keliru. Kelompok yang aktif diberi penghargaan oleh guru dengan kriteria kelompok super. Terakhir, guru mengajak siswa memberikan kesimpulan terhadap materi yang diajarkan.

Kemampuan berpikir kritis matematik merupakan suatu proses berpikir secara logis dan evaluatif yang dilihat berdasarkan kemampuan siswa dalam menganalisis, mengidentifikasi konsep, menghubungkan antarkonsep, memecahkan masalah dan mengevaluasi. Kemampuan berpikir kritis matematik diukur pada kelas eksperimen dan kelas kontrol berdasarkan skor pretest dan posttest yang dikonversi dalam nilai kualitatif. Hasil analisis tabel 4.3, rata-rata nilai pretest, yaitu 27,21. Artinya, pada kelas eksperimen sebelum diajar dengan pendekatan open ended setting model pembelajaran kooperatif tipe
STAD siswa sudah memiliki kemampuan berpikir kritis matematik. Walaupun demikian, rata-rata nilai yang diperoleh oleh siswa masih jauh dari nilai maksimal. Bahkan, tidak mencapai stengah dari nilai maksimal. Ini mengindikasikan bahwa kemampuan berpikir kritis matematik sebelum diajar dengan pendekatan open ended dalam setting model pembelajaran kooperatif tipe Student Teams Achievement Divisions (STAD) masih rendah. Sementara itu, rata-rata nilai posttest, yaitu 67,97 lebih dari setengah nilai maksimal. Ini mengindikasikan bahwa bahwa kemampuan berpikir kritis matematik setelah diajar dengan pendekatan open ended setting model pembelajaran kooperatif tipe STAD tergolong kategori tinggi. Kemampuan berpikir kritis matematik siswa lebih merata setelah diajar dengan pendekatan open ended setting model pembelajaran kooperatif tipe STAD. Ini disebabkan oleh pembelajaran yang digunakan berorientasi pada masalah yang diselesaikan secara berkelompok sehingga distribusi pengetahuan tersebar merata kepada semua siswa.

Berdasarkan banyaknya siswa yang memperoleh nilai di atas rata-rata, banyaknya siswa yang memiliki kemampuan berpikir kritis matematik di atas rata-rata sebelum diajar dengan pendekatan open ended setting model pembelajaran kooperatif tipe STAD, yaitu 15 orang lebih sedikit dibandingkan dengan setelah diajar dengan pendekatan open ended setting model pembelajaran kooperatif tipe STAD yaitu 19 orang. Atau jika dipresentasikan 62,5\% berbanding $79,17 \%$. Jika dilihat berdasarkan nilai minimum dan maksimum dari kedua jenis tes, nilai maksimum dari pretest mendekati nilai minimum dari posttest. Artinya, bahwa kemampuan maksimal berpikir kritis matematik siswa sebelum diajar dengan pendekatan open ended setting model pembelajaran kooperatif tipe STAD hampir setara dengan kemampuan minimal berpikir kritis matematik siswa setelah diajar dengan pendekatan open ended setting model pembelajaran kooperatif tipe STAD.

Skor pretest dan posttest selanjutnya diolah dengan Microsoft Excel 2010 untuk melihat peningkatan kemampuan berpikir kritis matematik siswa pada kelas eksperimen. Nilai ini dikenal dengan normalized gain. Rata-rata normalized gain merupakan gambaran peningkatan kemampuan berpikir kritis 
matematik siswa yang diajar dengan pendekatan open ended dalam setting model pembelajaran kooperatif tipe STAD. Sebelum melihat analisis deskriptif normalized gain peneliti terlebih dahulu mengklasifikasikan normalized gain. Tujuannya adalah untuk mengkategorikan peningkatan kemampuan berpikir kritis matematik pada kelas eksperimen apakah termasuk dalam kategori rendah, sedang atau tinggi. Di kelas eksperimen, tidak terdapat siswa yang memiliki peningkatan kemampuan berpikir kritis matematik kategori rendah. Hampir setengah dari banyaknya siswa memiliki peningkatan kemampuan berpikir kritis matematik kategori tinggi. Artinya, bahwa lebih dari setengah banyaknya siswa memiliki peningkatan kemampuan berpikir kritis matematik kategori sedang. Ini menunjukkan bahwa setelah diajar dengan pendekatan open ended setting model pembelajaran kooperatif tipe STAD secara keseluruhan siswa sudah mampu menggunakan kemampuan berpikir kritis matematiknya.

Deskripsi peningkatan kemampuan berpikir kritis matematik juga dapat dilihat berdasarkan peningkatan kemampuan berpikir kritis matematik tiap indikator. Hasil analisis tabel 4.7 terlihat bahwa kemampuan berpikir kritis matematik siswa pada masing-masing indikator mengalami peningkatan. Klasifikasi normalized gain tiap indikator pada kelas eksperimen paling banyak kategori sedang, yaitu indikator mengidentifikasi konsep, menghubungkan antar konsep, memecahkan masalah dan mengevaluasi. Sedangkan indikator menganalisis tergolong kategori tinggi. Peningkatan kemampuan berpikir kritis matematik tiap indikator disebabkan oleh penerapan pendekatan open ended setting model pembelajaran kooperatif tipe STAD. Pembelajaran ini memacu siswa untuk lebih aktif dalam menentukan cara penyelesaian masalah/soal yang diberikan oleh guru.

Indikator menganalisis kemampuan berpikir kritis matematik siswa mengalami peningkatan kategori tinggi. Dalam menyelesaikan masalah/soal yang menghendaki jawaban atau cara penyelesaian yang banyak dibutuhkan pengetahuan yang luas mengenai materi yang diajarkan. Ini akan memacu siswa untuk mengembangkan kemampuan menganalisisnya sehingga dapat merinci secara detail apa yang diketahui dan ditanyakan dari soal. Sehingga siswa dapat menganalisis setiap permasalahan tersebut dari berbagai sudut pandang. Hasil analisis tersebut selanjutnya didiskusikan dengan teman kelompoknya. Kemampuan siswa dalam menyerap informasi hasil diskusi tentang menganalisis masalah/soal sudah baik. Artinya, secara keseluruhan siswa sudah mampu menuliskan apa yang diketahui dan ditanyakan dari permasalahan yang diberikan.

Indikator mengidentifikasi konsep mengalami peningkatan kategori sedang. Artinya, masih terdapat siswa yang belum menggunakan indikator mengidentifikasi konsep dengan baik. Masalah/soal terbuka yang diberikan menuntut siswa untuk merencanakan penyelesaian masalah yang tepat. Perencanaan penyelesaian masalah menghendaki siswa untuk mengidentifikasi konsep/definisi/teorema secara tepat agar melahirkan berbagai macam gagasan. Siswa belum maksimal menentukan berbagai konsep/definisi/teorema yang diperlukan dalam memecahkan masalah walaupun pada pelaksanaannya guru menggunakan alat peraga. Hasil indentifikasi konsep dengan alat peraga selanjutnya didiskusikan dengan kelompoknya. Faktanya, dalam aspek ini indikator mengevaluasi juga termasuk dalam kategori sedang.

Hasil analisis deskripsi statistik menunjukkan bahwa rerata normalized gain kemampuan berpikir kritis matematik siswa pada kelas eksperimen, yaitu 0,6088. Berdasarkan rerata normalized gain ini kemampuan berpikir kritis matematik siswa termasuk dalam kategori sedang. Lebih dari setengah jumlah siswa memiliki peningkatan kemampuan berpikir kritis matematik di atas rata-rata. Setelah diajar dengan pendekatan open ended setting model pembelajaran kooperatif tipe STAD tidak ada siswa yang tidak menngunakan kemampuan berpikir kritis matematiknya dengan baik. Dengan kata lain, peningkatan terendah kemampuan berpikir kritis matematik siswa tergolong dalam kategori sedang. Hal ini mengindikasikan bahwa dari aspek rerata normalized gain, terdapat peningkatan secara signifikan kemampuan berpikir kritis matematik siswa setelah diajar dengan pendekatan open ended dalam setting model pembelajaran kooperatif tipe STAD. Kemampuan berpikir kritis matematik siswa meningkat secara merata. Ini menunjukkan bahwa pembelajaran dengan pendekatan open ended dalam setting model pembelajaran 
kooperatif tipe STAD sudah menjadikan siswa memiliki kemampuan berpikir kritis matematik seperti yang diharapkan.

Peningkatan secara signifikan kemampuan berpikir kritis matematik diketahui setelah dilakukan uji hipotesis rata-rata normalized gain pada kelas eksperimen dengan menggunakan uji t satu sampel. Namun, terlebih dahulu dilakukan uji prasyarat hipotesis, yaitu uji normalitas. Hasil analisis menunjukkan bahwa data kelas eksperimen berdistribusi normal (Asymp.Sig. (2-tailed) kelas eksperimen lebih besar dari setengah $\alpha$ ). Berdasarkan uji hipotesis, terdapat peningkatan secara signifikan kemampuan berpikir kritis matematik yang diajar dengan pendekatan open ended setting model pembelajaran kooperatif tipe STAD. Dengan kata lain, terdapat pengaruh pendekatan open ended dalam setting model pembelajaran kooperatif tipe STAD terhadap peningkatan kemampuan berpikir kritis matematik siswa.

Peningkatan kemampuan berpikir kritis matematik siswa secara signifikan diperoleh siswa yang diajar dengan pendekatan open ended setting model pembelajaran kooperatif tipe STAD ini disebabkan oleh orientasi pembelajaran yang berbasis masalah/soal-soal terbuka sehingga siswa bebas untuk mengekspresikan ide-ide mereka sesuai dengan yang diinginkan. Masalah menjadi titik tolak pembelajaran untuk memahami konsep dan mengembangkan kemampuan berpikir kritis matematik. Hal ini memberikan kesempatan kepada siswa untuk menghasikan berbagai macam ide/gagasan. Berkaitan dengan ini, kemampuan menganalisis masalah sangat penting. Kemampuan dalam menganalisis masalah membantu siswa dapat menuliskan apa yang diketahui dan ditanyakan dari masalah/soal yang diberikan. Masalah/soal terbuka memiliki banyak tujuan. Akibatnya, siswa dapat menunjukkan kemampuan mereka dalam menentukkan berbagai konsep yang dibutuhkan dalam menyelesaikan masalah. Disisi lain, keterbukaan soal dapat mengundang rasa kecurigaan siswa sehingga siswa melakukan pemeriksaan terhadap konsep-konsep matematik yang relevan.

Keterbukaan soal dapat mendatangkan berbagai tanggapan sehingga siswa dapat menjelaskan pemikiran mereka karena tidak semua pemikiran mereka sama. Desain permasalahan dalam lembar kerja peserta didik yang selalu dinyatakan dalam situasi fisik yang nyata memacu siswa untuk mengamati dan mengkaji konsep matematika secara intensif. Siswa merasa tertarik sebab ada banyak kemungkinan penerapan berbagai pendekatan dan strategi dalam penyelesaiannya. Hal ini mendorong siswa untuk menghubungkan antarkonsep yang diperolehnya melalui hasil pengamatan dan kajian tadi untuk menyelesaikan masalah yang diberikan. Hal ini sejalan dengan pendapat Tyler (Redhana, 2003: 14) bahwa pengalaman atau pembelajaran yang memberikan kesempatan kepada siswa seluasluasnya untuk memperoleh keterampilan dalam memecahkan masalah dapat merangsang keterampilan berpikir kritis matematik siswa.

Proses penyelesaian matematika dalam dunia nyata terkadang tidak bisa langsung diterapkan pada kondisi tertentu melainkan harus dimodelkan secara matematis. Kegiatan ini mengajak siswa untuk terlibat aktif dalam proses pembelajaran. Lingkungan belajar yang menghendaki siswa untuk terlibat secara aktif adalah dengan pembelajaran berkelompok, yaitu model pembelajaran kooperatif tipe Student Teams Achievement Divisions (STAD). Sehingga, dengan belajar berkelompok masalah yang kompleks menjadi lebih mudah dipahami dan dipecahkan karena menjadi tanggung jawab bersama dalam tiap-tiap kelompok. Hasil pengkajian dan proses penyelesaian masalah yang diperoleh masing-masing siswa menjadi milik bersama. Hal ini sejalan dengan pendapat sosial Vigotsky (Sani, 2015:19) bahwa aktivitas siswa yang aktif seharusnya didukung dengan lingkungan belajar yang menitikberatkan kerja sama. Peserta didik berpartisipasi dalam kegiatan sosial tanpa makna, kemudian terjadi internalisasi atau pengendapan pengetahuan dan pemaknaan atau konstruksi pengetahuan baru, serta perubahan atau transformasi pengetahuan. Penguatan pemahaman yang lebih tinggi pada umumnya muncul dalam percakapan dan kerja sama antarindividu sebelum pemahaman yang lebih tinggi itu terserap ke dalam individu tersebut. Lingkungan belajar yang saling bekerja sama akan membantu siswa dalam mengontruksi pengetahuan. Peran masing-masing siswa dalam kelompoknya sebagai pelajar dan pengajar. Artinya, selain mendapat pengetahuan dari teman kelompoknya siswa juga menularkan pengetahuan yang dimilikinya. Pengetahuan yang dimiliki oleh masing-masing siswa 
merupakan hasil tanggapan terhadap masalah/soal terbuka yang disajikan.

Membiasakan siswa untuk berpikir secara bebas merupakan cara yang efektif untuk meningkatkan kemampuan berpikir kritis matematik. Pengetahuan yang diperoleh oleh siswa dengan pembelajaran ini lebih mendalam dan berkesan karena siswa menemukan sendiri pengetahuannya dan siswa tidak terikat secara prosedural untuk menyelesaiakn masalah matematik. Selain itu, pemberian reward atau penghargaan kepada kelompok akan memacu siswa untuk belajar lebih giat lagi. Siswa merasa berkompetisi sehingga mereka terdorong untuk menggunakan pengetahuan yang dimilikinya secara komprehensif. Artinya bahwa pembelajaran ini cocok diterapkan untuk meningkatkan kemampuan berpikir kritis matematik siswa. Sudah saatnya guru matematika untuk menerapkan pembelajaran ini agar mutu hasil belajar matematika siswa sesuai dengan harapan kurikulum.

\section{Simpulan dan Saran}

\section{Simpulan}

Berdasarkan hasil analisis dan pembahasan diatas dapat disimpulkan bahwa:

1. Kemampuan berpikir kritis matematik setelah diajar dengan pendekatan openended setting model pembelajaran kooperatif tipe STAD di kelas VII SMP Negeri 1 Wakorumba Selatan paling banyak dalam kategori tinggi.

2. Peningkatan kemampuan berpikir kritis matematik yang diajar dengan pendekatan open-ended setting model pembelajaran kooperatif tipe STAD di kelas VII SMP Negeri 1 Wakorumba Selatan paling banyak termasuk kategori sedang.

3. Terdapat pengaruh positif pendekatan open-ended setting model pembelajaran kooperatif tipe STAD terhadap peningkatan kemampuan berpikir kritis matematik siswa di kelas VII SMP Negeri 1 Wakorumba Selatan. Atau dengan kata lain, terdapat peningkatan kemampuan berpikir kritis matematik siswa setelah diajar dengan pendekatan open-ended setting model pembelajaran kooperatif tipe STAD.

\section{Saran}

Berdasarkan hasil analisis, pembahasan, dan kesimpulan dalam penelitian ini dapat dikemukakan saran-saran sebagai berikut.

1. Guru matematika hendaknya dapat menggunakan pembelajaran dengan pendekatan open-ended setting model pembelajaran kooperatif STAD untuk memaksimalkan kemampuan berpikir kritis matematik siswa.

2. Kemampuan berpikir kritis matematik perlu mendapat perhatian lebih dari para guru matematika karena kemampuan ini bersifat aplikatif dalam kehidupan sehari-hari.

\section{Daftar Pustaka}

Akbar, S \& Usman (201) Pembelajaran Matematika. Jakarta: Universitas Terbuka.

Becker, J.P., \& Shimada,S (2007) The OpenEnded Approach: A New Proposal for Teaching Mathematic. Virgina: NCTM

Eminingsih (2013) Peningkatan Hasil Belajar Matematika Melalui Pembelajaran Kooperatif Tipe STAD pada Siswa Kelas VII E SMP Negeri 3 Batang. Lembaran Ilmu Kependidikan volume 42 nomor 1. Agustus 2013.UPI. Bandung.

Ficher, A. (2008) Berpikir Kritis: Sebuah Pengantar, alih bahasa: Benyamin Hadinata, Erlangga, Jakarta.

Irianto, A (2015) Statistik: Konsep Dasar, Aplikasi, dan Pengembangannya. Semarang: Prenadamedia.

Jenicek, M (2006) A Physician's Self-Paced Guide to Critical Thingking. Chicago: United States of America.

Karso (2011) Pendidikan Matematika I. Jakarta: Universitas Terbuka.

Krismantono (2003) Beberapa Teknik, Model dan Strategis dalam Pembelajaran Matematika. Yogyakarta: Widyaswara.

Lambertus \& Hamid, M. M (2014) Efektivitas Pembelajaran Berbasis Masalah Terhadap Peningkatan Kemamapuan 
Berpikir Kritis Matematik Siswa Kelas VII SMP Negeri 14 Kendari. Jurnal Penelitian Pendidikan Matematika volume 2 nomor 2. Mei 2014. FKIP UHO. Kendari.

Mahmudi, A. (2008) Makalah Mengembangkan Soal Terbuka (Open-Ended Problem) Dalam Pembelajaran Matematika, disampaikan pada seminar nasional matematika pada Pendidikan Matematika FMIPA UNY Yogyakarta pada Jumat, 28 November 2008.

Nohda, N (2008) A Study of "Open-Approach" Method in School Mathematics Teaching -Focusing On Mathematical Problem Solving Activities. dilihat 15 Desember 2017, http://www.nku.edu/ sheffield/nohda. html >.

Redhana, I. W (2003) Meningkatkan Keterampilan Berpikir Kritis Siswa Melalaui Pembelajaran Kooperatif dengan Strategi Pemecahan Masalah. Jurnal Pendidikan dan Pengajaran volume 26 nomor 2. Juli 2013. FKIP Universitas Udayana. Bali.
Sani, Ridwan A (2015) Inovasi Pembelajaran. Jakarta: Bumi Aksara.

Sugiyono. 2009. Metode Penelitian Kuantitatif, Kualitatif, dan $R$ \& $D$. Bandung: Alfabeta.

Suherman, E. 2003. Strategi Pembelajaran Matematika Kontemporer. Ed. 2. Universitas Pendidikan Indonesia: Bandung.

Sundayana, A. (2014) Metodologi Penelitian, PT. Rineka Cipta, Jakarta.

Usman, H., \& Akbar, P. S. (2008) Pengantar Statistika, edisi kedua, Bumi Aksara, Jakarta. 